\title{
The Challenge OF
}

TEMPORARY WORK IN

TWENTY-FIRST CENTURY LABOR MARKETS

FLEXIBILITY WITH FAIRNESS FOR THE LOW-WAGE TEMPORARY WORKFORCE

HARRIS FREEMAN

WESTERN NEW ENGLAND UNIVERSITY

SCHOOL OF LAW, SPRINGFIELD

GEORGE GONOS

STATE UNIVERSITY OF NEW YORK, POTSDAM

A WORKING PAPER ON THE FUTURE OF WORK IN MASSACHUSETTS PUBLISHED BY THE LABOR RELATIONS AND RESEARCH CENTER UNIVERSITY OF MASSACHUSETTS, AMHERST 


\section{RESEARCH AND ACKNOWLEDGMENTS}

The data and findings presented herein build on and add to a small but growing body of research that explores the adverse social and economic impacts associated with the rapid growth of temporary staffing agencies and other commercial labor market intermediaries in the low-wage industrial and service sectors of the economy. Our report is based on several sources of information:

- Statistical data compiled from U.S. Census Data and the U.S. Bureau of Labor Statistics;

- Information about working conditions as reported by workers in focus groups conducted in eastern cities in the Bay State, through interviews conducted with staff from community worker centers throughout Massachusetts, attorneys representing temporary workers in legal cases, and as conveyed by temp workers in testimony to the Massachusetts legislature;

- Information on labor violations gathered from federal and state agency reports, reported legal decisions and press coverage;

- Quantitative and qualitative research compiled from numerous local and national studies of the temporary staffing industry and the low-wage workforce.

We would like to extend our thanks and gratitude to the many individuals and organizations that provided invaluable information and gave freely of their time to assist us in preparing this report. We are especially grateful because part of the magnitude of the problem is the difficulty of gathering data about the disquieting realities of temporary work that is performed by seemingly invisible workers in the shadows and ignored corners of the low-wage labor market. Finally, we would like to thank the faculty and staff of the Labor Relations and Research Center at the University of Massachusetts for the opportunity to be part of their ongoing discussions and research on the future of work in Massachusetts.

\section{ABOUT THE AUTHORS}

Harris Freeman, JD, is Associate Professor of Legal Research and Writing at Western New England University School of Law in Springfield. From 1999 until 2009, he was a long-term visiting professor at the Labor Relations and Research Center at the University of Massachusetts, Amherst. His research in the areas of labor relations and workplace laws that impact non-standard workers has appeared in both law and labor studies journals.

George Gonos, $\mathrm{PhD}$, is Professor of Sociology and Employment Relations at the State University of New York, Potsdam. His research examining the legal and political dimensions of temporary work and other forms of contingent labor has been widely published in academic journals. He has long worked with community-based labor organizations on advocacy and organization development for low-wage workers. 


\section{CONTENTS}

- $\quad$ EXECUTIVE SUMMARY 3

I. INTRODUCTION: THE TEMPING OF AMERICA 9

II. THE ABUSE OF LOW-WAGE TEMPS IN MASSACHUSETTS: RECURRENT WAGE THEFT AND Routine Violations OF HEALTH AND SAFETY LAWS

III. LOW-WAGE TEMPS IN MASSACHUSETTS:

A SeCond-Tier Workforce Vulnerable to Wage TheFt AND UNSAFE WORKPLACE CONDITIONS

IV. CREATING FleXIBILITY WITH FAIRNESS: Amending Employment Agency LaW to Protect the LOW-WAGE TEMP WORKFORCE 29

- $\quad$ ENDNOTES 35 


\section{EXECUTIVE SUMMARY}

As the Commonwealth wrestles with the social and economic aftershocks of the worst economic recession in 80 years, the widespread use of temporary staffing arrangements is a sober reminder that the "standard" employment relationship, a cornerstone of the prosperity of the post-World War II era, is no longer available to a large segment of the American workforce. "Job ladders" have disintegrated, depriving capable and dedicated workers of predictable promotions. Regular step increases in pay and cost-of-living adjustments are in many occupational categories a thing of the past. ${ }^{1}$ Simply put, the "good jobs" working people need to support families, pay the mortgage and finance a college education are far too scarce. ${ }^{2}$

This report provides policy-makers an assessment of temporary low-wage work in Massachusetts as it affects workers, businesses, and the growth of the Massachusetts economy. Each day, about 25,000 temporary staffing agency workers toil in low-wage industrial and service jobs in the Commonwealth. ${ }^{3}$ These workers, like hundreds of thousands of Americans, hold down precarious staffing jobs characterized by erratic schedules, poverty wages, hazardous conditions and demeaning treatment.

\section{FINDINGS}

The low-wage temporary workforce at the center of this study is sizable, growing rapidly, and holds far-reaching implications for the future of work. Our findings on the size and socio-economic conditions of the low-wage temporary workforce point to five major problems confronting the Commonwealth:

\section{Finding 1: Low-wage temporary staffing agency workers comprise a rapidly growing and vulnerable segment of an unregulated labor market.}

The pressures of globalization and employer efforts to "right-size" their workforces have placed the temporary help staffing industry at the center of today's lean and flexible employment paradigms. Low-wage temp work is part of the 'new normal,' contributing to the creation a workforce that has seen its real earnings stagnate or decline, and its economic security wane.

- $\quad$ Across America, as the availability of quality jobs has declined, lowwage, temporary work has mushroomed, expanding into almost every economic sector. The northeastern region of the U.S. experienced a $68 \%$ jump in temporary help service employment over the course of the last two decades. ${ }^{4}$ 
- $\quad$ More than one-third of temp agency workers in Massachusetts are now low-wage industrial and service sector employees.

- Employment through temporary staffing agencies will continue expanding more rapidly in the low-wage economy than in other economic sectors.

- $\quad$ Most often, temp workers are second-class citizens in the workplace as the benefits and expectations attendant to long-term, standard employment relationships are non-existent. Within the contingent workforce as a whole, temporary agency workers are the lowest paid.

- When compared to standard employees, the temp worker population tends to be younger, less educated and disproportionately comprised of minority workers. Immigrant workers are a growing component of the low-wage temporary workforce in urban centers throughout Massachusetts.

- $\quad$ The vulnerability of the low-wage temporary workforce is most acute in the shadows of the underground economy, where lowroad temporary agencies and unscrupulous employers often operate with impunity.

- "Permatemping" is on the rise. In certain industries, low-wage temps are now systematically used to staff entire job clusters and occupations indefinitely.

- $\quad$ Throughout Massachusetts, low-wage temps are deployed to work in residential construction, landscaping, fish and meat processing, hotels and restaurants, recycling centers, rock cutting, food processing, manufacturing, warehousing, cranberry harvesting, freight handling, demolition, waste hauling, cleaning and janitorial services.

\section{Finding 2: The triangular employment relationship, a hallmark of the temporary industry, presents unique challenges for the enforcement of wage and hour laws in the low-wage economy.}

A pattern of unscrupulous conduct in sectors of the low-wage staffing industry is evident statewide. Interviews with temp workers, worker centers' staff, focus group research conducted among the low-wage temp workforce, along with legal complaints and press reports paint a picture of law breaking and wage theft in a wide-range of workplaces. The following are examples: 
- Springfield: As for back as 2001, one of the nation's largest temporary help agencies, Labor Ready Northeast, was charged with wage and hour violations by the Massachusetts Attorney General's Office. Ultimately, Labor Ready paid $\$ 250,000$ in wages and penalties.

- Chelsea: Hundreds of immigrant temps are shuttled each day from Boston's urban center to abusive workplaces throughout Massachusetts and southern New Hampshire in overcrowded temp agency vans. Temps report endemic wage theft, being ordered to work "off the clock," and being charged mandatory transportation fees.

- Natick: In the summer of 2010, a popular high-end restaurant chain and marginal temp agency colluded to deny its Latino kitchen staff of overtime pay and earned wages. The restaurant told the workers it was closing and would pay them after it closed its doors for good. When the restaurant closed, the workers first learned they were actually employed by a temp agency. That agency has closed its doors without paying wages owed to these temps.

Worcester: Temps employed at a stone cutting business were victimized and cheated out of overtime pay using a "check splitting" scheme. After working up to 70 hours per week, the workers received two checks without any overtime pay, one from the temp agency and a second from the granite business.

\section{Finding 3: Blurred lines of employer responsibility and widespread malfeasance of low-road temporary agencies and their client businesses have resulted in the under-enforcement of safety standards for temp workers.}

Temp workers are employed in some of the state's most hazardous jobs, including waste recycling, fish processing and construction. With little information about the nature of their jobs and an absence of safety training, workers report retaliation for health and safety complaints along with an increased risk of work-related injuries and illnesses.

- In 2009, a chemical release at a major recycling and disposal center that contracted with the City of New Bedford sent 117 workers to the hospital. The vast majority were Mayan immigrants, farmed out to recycling center by a temp agency. 
- Temps employed in waste recycling report a failure to provide them with basic information on job safety including the need for vaccinations to prevent infections and illnesses associated with handling hazardous materials.

- Temps employed in fish processing report not being provided safety equipment and having to purchase protective gear necessary to perform their jobs.

- Temporary staffing agencies in the low-wage sector commonly obscure the fact that the agency is the insurance carrier and fail to inform temp workers about how and where to file workers' compensation claims.

\section{Finding 4: Taxpayers and government are burdened by temporary agency fraud that is amounting to tens of millions of dollars in lost revenue.}

Temporary staffing agency fraud is costing the Commonwealth and federal government tens of millions of dollars. For example, in 2010, two staffing agencies in Massachusetts were identified as responsible for as much as $\$ 45$ million in unpaid workers' compensation insurance, federal withholdings, Social Security and Medicaid taxes.

In this summary, we have outlined our findings indicating the problems linked to the growing low-wage temporary staffing workforce. To be clear, not all low-wage temporary staffing agencies are violating the law. However, many large and small businesses are using an unscrupulous cohort of temp agencies to systematically evade employment and labor laws, subjecting low-wage temp workers to a host of illegal practices. Of critical concern are those findings pointing to widespread violations of basic wage and hour standards, collusion to ignore vital health and safety laws, and concerted efforts by certain temp agencies and their clients to evade taxes and mandated insurance payments.

The adverse impacts of these untoward staffing agency practices keep families in poverty and compromise the vitality of local communities. The evasion and violation of core laws governing the workplace has set off a race to the bottom that threatens to make sub-minimum wages and safety violations normative business practices in the low-wage labor market.

If left unchecked by policy-makers, these problems will promote a business climate that makes it increasingly difficult for law-abiding staffing agencies and responsible employers to compete and survive. Accordingly, we offer a series of proposals for legislative action. 


\section{FLEXIBILITY WITH FAIRNESS: RECOMMENDATIONS FOR LEGISLATIVE ACTION}

The current regulatory framework intended to protect vulnerable elements of the labor force is not working for temp workers who routinely encounter unscrupulous staffing agencies in the low-wage sectors of the Massachusetts economy. At the center of this regulatory failure is the Commonwealth's outdated Employment Agency Law, ${ }^{5}$ a set of once-progressive standards that have not been updated in almost half a century. As it now stands, the Massachusetts Employment Agency Law neither prevents or provides meaningful remedies for recurring, flagrant violations of workplace law committed by certain temporary employment agencies and client businesses that prey on workers in the low-wage economy.

We propose four critical changes to the Massachusetts Employment Agency Law if we are going to create fairness for the 21st century's low-wage temporary staffing workforce while maintaining the flexibility that employers are demanding to keep pace in today's globalized economy.

ONE Eliminate the double standard in Massachusetts Employment Agency Law that currently regulates professional employment agencies but leaves the temporary staffing industry unregulated.

An over-complicated and outdated bureaucratic scheme regulates permanent placement agencies while the law provides no regulatory oversight for low-wage temporary help services. This regulatory disparity is problematic because the temporary staffing agency business - the unregulated portion of the employment services industry - now comprises well over $70 \%$ of the employment agency business in Massachusetts and elsewhere.

The law must be overhauled to include protections for the large number of lowwage temp workers that fall outside of the protections in the current law and streamlined to make registration and compliance less onerous for permanent employment agencies. 
TwO Create transparency and provide temp workers with basic information about the terms and conditions of work before starting a job assignment.

Temp workers are routinely deployed to client businesses without having basic information about wages and terms and conditions of employment. Even the name of the employer is often not provided and hidden costs of employment can be deducted without advance warning.

Temp agencies should be required to provide low-wage temps with basic information in writing about wages and terms ad conditions of employment, particularly regarding issues related to health and safety.

\section{THREE Provide meaningful enforcement of labor standards for the temporary workforce.}

Enforcement of laws protecting low-wage temps requires pro-active government monitoring and the ability of workers to seek legal redress without fear of retaliation for violations of the law by abusive temp agencies and client employers.

Reform is needed to provide temp workers with an anti-retaliation provision and a private right of action to enforce the law.

FOUR Level the playing field for all commercial employment agencies through reforms that streamline the law and support enforcement of labor standards for low-wage, vulnerable temp workers.

Reform of the Commonwealth's Employment Agency Law is necessary to create a level playing field that can ensure that good jobs are created in Massachusetts as businesses, including law abiding staffing agencies and their employees, work hard to hasten economic recovery and facilitate renewed prosperity for all. 


\section{The Challenge of Temporary Work in the Twenty- FIRST CENTURY ECONOMY: FLEXIBILITY WITH FAIRNESS FOR THE LOW-WAGE TEMPORARY WORKFORCE}

\section{INTRODUCTION - THE TEMPING OF WORK IN AMERICA}

Since 1980, temporary agencies have experienced spectacular growth, expanding into almost every economic sector. ${ }^{6}$ Between 1990 and 2008, the number of temporary agency workers deployed to business each day more than doubled. ${ }^{7}$ According to the American Staffing Association, on an average day, the staffing industry deploys as many as 3 million temp workers and contract employees at all income and skill levels. ${ }^{8}$ Moreover, temp agency jobs constitute a growing proportion of all new jobs created in the U.S. In 2010, the Bureau of Labor Statistics reported that of the 1.12 million jobs created, more than 27 per cent were temporary help staffing positions, a greater proportion than in the previous two recoveries. $^{9}$

Temporary employment is now ubiquitous. In a given year, an astonishing $90 \%$ of American businesses use temp labor. ${ }^{10} \mathrm{And}$, because turnover is endemic in this industry, as much as $10 \%$ of the working population is engaged in some temp work annually. As we entered the 21st century, the annual sales of the temporary staffing industry exceeded $\$ 64$ billion dollars.

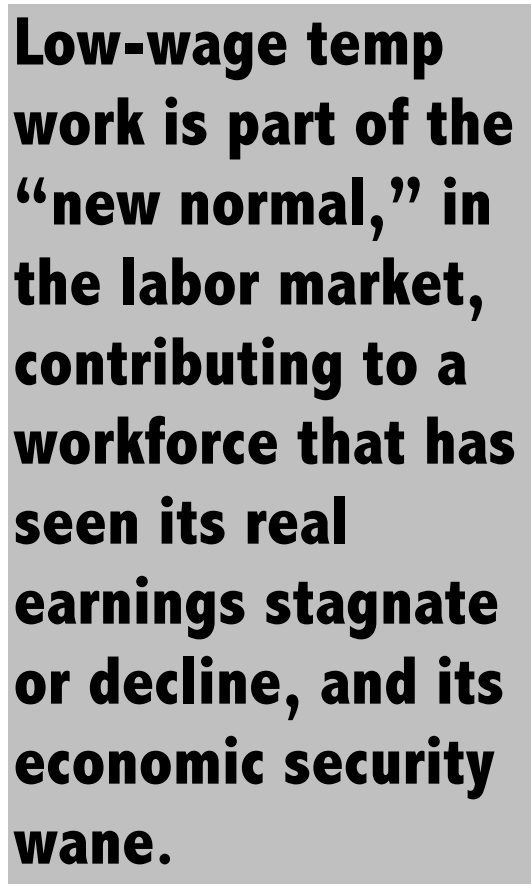

The growth of temp employment in Massachusetts mirrors its meteoric growth nationwide. The northeastern region of the U.S. experienced a $68 \%$ jump in temporary agency employment over the course of the last two decades. ${ }^{11}$ Consider that in 1963 there were less than 20 "temporary job services" in the Commonwealth, with yearly gross business estimated at $\$ 4.5$ million. ${ }^{12}$ In 2008 , the U.S. Census counted no less than 941 commercial temporary help firms in the Commonwealth employing around 65,720 temp agency workers each day. ${ }^{13}$

\section{A. The Characteristics of Low-Wage Temporary Employment}

Employment through temporary staffing agencies has been expanding more rapidly in the low-wage economy than in other economic sectors. So-called "blue collar" temp work in the manufacturing and service sectors is the fastest growing segment 
of the temporary industry. Back in 1985 , blue-collar temp constituted only $6 \%$ of the temp agency workforce; by 1997, they accounted for approximately $30 \%$ of the temporary staffing workforce and make up over 35\% of the temporary workforce today. ${ }^{14}$ Symptomatically, Labor Ready, a nationwide temporary staffing business focusing on "industrial" temping, expanded from fewer than twenty offices in 1993 to about 800 in 2005.15

Projected U.S. INCREASE IN LOW-WAGE TEMPORARY WORK 2006 -2016

\begin{tabular}{|l|c|c|}
\hline Occupation & $\begin{array}{l}\text { Temporary } \\
\text { Staffing Workforce } \\
\text { in 2006 }\end{array}$ & $\begin{array}{l}\text { Expected Percentage } \\
\text { Increase 2006-2016 }\end{array}$ \\
\hline Janitors/Cleaners & 20,000 & +29.4 \\
\hline Shipping/Receiving & 44,000 & +21.8 \\
\hline Construction/Extraction & 178,000 & +22.6 \\
\hline Manufacturing/Production & 361,000 & +17.6 \\
\hline Logistics/Warehousing & 469,000 & +13.9 \\
\hline Landscaping & 28,000 & +11.1 \\
\hline
\end{tabular}

Temporary employment in Massachusetts is in line with these national trends. More than one-third of temp agency workers in the Commonwealth are low-wage industrial and service sector employees. ${ }^{17}$ These low-wage temps are deployed to work in residential construction, landscaping, fish and meat processing, hotels and restaurants, recycling centers, rock cutting, food processing, manufacturing, warehousing, cranberry harvesting, freight handling, demolition, waste hauling, cleaning and janitorial services. The work is often dirty, difficult, dangerous, and, usually, essential.

\section{The Demographics of a Vulnerable Workforce}

Temporary work is by definition precarious; most often, the benefits and expectations attendant to long-term standard employment relationships are nonexistent. Within the contingent workforce ${ }^{18}$ as a whole, temporary agency workers are the lowest paid. ${ }^{19}$ When compared to standard employees, the temp worker population tends to be younger, less educated ${ }^{20}$ and disproportionately comprised of minority workers. ${ }^{21}$ 
Research also indicates that temp agency employees experience a pervasive absence of health and retirement benefits. Only 8\% of temporary help workers receive health insurance from the staffing agency. Temps are also often denied other fringe benefits commonly offered to standard employees, including paid vacations, life insurance, and sick days. Retirements benefits, like health care, are not a reality for the vast majority of temps. Only $9 \%$ of temp agency workers receive any pension benefits compared to $53 \%$ of workers in traditional jobs. ${ }^{22}$

Note, however, that in the low-wage sector of the temporary staffing industry, all the above-referenced indices of precariousness and vulnerability increase exponentially. Moreover, while statistics are not available, all evidence points to a low-wage temporary workforce that includes large numbers of immigrants and undocumented workers whose vulnerabilities are exacerbated by language and literacy barriers as well as legal status. ${ }^{23}$

It is also important to consider that temp agency workers are no longer just short-term replacements, merely "filling-in" for sick full-timers or employees on leave or vacation. While temp agency workers are still commonly used to cover for absent employees, or as purely supplemental staff during peak periods of demand, there has also developed a more systematic use of temps to staff entire job clusters and industries indefinitely. ${ }^{24}$ In certain markets, low-wage occupational niches like warehousing are increasingly "temped out" on a permanent basis, giving rise to a status aptly

Low-wage temporary workers comprise an essential, but second-class workforce.

There is no long-term pay-off for temp work; little evidence supports the urban myth that low-wage temp work provides a path to permanent, standard employment outcomes. labeled with the oxymoron, "permatemps" to describe this phenomenon. ${ }^{25}$ Permatemps in low-wage industrial and service jobs typically report for full-time work everyday - for months or even years - but lack any of the benefits or rights associated with permanent employment.

The low-wage "temporary" workforce now comprises an essential, but second-class workforce in many sectors of the economy. ${ }^{26}$ It is not surprising that most lowwage temps find temporary agency employment unsatisfactory. ${ }^{27}$ And there is no long term pay-off for temp work; little evidence supports the urban myth associated with temp work, particularly that temping provides a path to permanent standard employment outcomes. Indeed, leading researchers have concluded that in the low wage arena "temporary-help job placements does not improve, and may in fact diminish, subsequent earnings" and adversely impact future employment outcomes among participants. ${ }^{28}$ 


\section{B. A Shadow Workforce: Temp Workers in the Underground Economy}

The temporary staffing industry has widened its reach in low-wage industrial and service sectors during a time when reduced enforcement of fundamental wage and hour standards has created a lawless "gloves off economy" in these labor markets. Unlike earlier generations of American workers, it if far more likely that these lowwage workers will not be paid for all hours worked and will not receive earned overtime pay. ${ }^{29}$

The dynamic of the lawless, "gloves off" economy is most acute in the underground economy of the Commonwealth's urban centers. ${ }^{30}$ In this shadow economy it doesn't take much to set up a lucrative job-brokering temp business. A cell phone, even without a formal business location is "capital" enough to run a fly-by-night temp agency in poor immigrant communities, turning a profit by farming out temporary employees to unscrupulous employers in a wide array of service, manufacturing and construction jobs. ${ }^{31}$

The underground economy presents a serious threat to workers, employers, tax revenues and the overall wellbeing of our Commonwealth. As Governor Deval Patrick has explained, ${ }^{32}$ the underground economy:

- $\quad$ exploits vulnerable workers and deprives them of legal benefits and protections;

- $\quad$ gives unlawful businesses an unfair competitive advantage over lawful businesses by illegally driving down violators' taxes, wages, and other overhead costs;

- defrauds the government of substantial tax revenues; and

- $\quad$ harms consumers who suffer at the hands of unlicensed businesses that fail to maintain minimum levels of skills and knowledge.

Massachusetts is among those states actively combatting fraudulent employment practices in the underground economy. ${ }^{33}$ Investigations conducted by Governor Patrick's Joint Enforcement Task Force on the Underground Economy and Employee Misclassification has already targeted some rogue staffing agencies. ${ }^{34}$ Recognizing the scope of the problem, the Task Force reorganized its investigative unit in 2010 to create a work group focused on problems posed by temporary employment agencies in the Massachusetts underground economy. ${ }^{35}$ 


\section{The Abuse of LoW-Wage Temps in Massachusetts: Recurrent WAGE THEFT AND ROUTINE VIOLATIONS OF HEALTH AND SAFETY LAWS}

The current regulatory framework intended to protect vulnerable elements of the labor force is not working for temp workers who routinely encounter unscrupulous staffing agencies in the low-wage sectors of the Massachusetts economy. Large and small businesses use these temp agencies to systematically evade employment and labor laws, subjecting low-wage temp workers to a host of illegal practices. Lowwage temps report wage theft, unsafe workplaces, and a lack of information about basic workplace health and safety conditions - even the name and address of their worksite employer - as the areas of greatest concern. Moreover, a well-founded fear of retaliation in the form of blacklisting and threats of deportation effectively disenfranchises temp workers and tends to quell complaints about even the most pernicious violations of workplace standards.

At the center of this regulatory failure is the Commonwealth's outdated Employment Agency Law, ${ }^{36}$ an outdated set of once-progressive standards that have not been updated in almost half a century. As it now stands, the Massachusetts Employment Agency Law neither prevents or provides meaningful remedies for recurring, flagrant violations of workplace law committed by certain temporary employment agencies and client businesses that prey on workers in the low-wage economy. These unscrupulous elements of the staffing agency industry are contributing to a business climate that puts all workers at risk and undermines the ability of the law-abiding staffing agencies to serve the varied employment needs of the business community in Massachusetts.

Absent basic reforms to address the unique problems facing low-wage temps, this workforce will remain vulnerable to wage theft, health and safety problems. A significant number will continue to fall victim to super-exploitation in underground temp labor markets. The efforts that government, business and labor are now taking to create sustainable living wage jobs will surely be compromised if legal reform does not check the unscrupulous staffing practices that undermine basic fairness in the low-wage workforce.
Unscrupulous elements of the staffing agency industry contribute to a business climate that puts all workers at risk, undermining the competitive position of employers who play by the rules. 
A. Temp Stories: Wage Theft, Exploitation and Abuse - from Springfield to New Bedford

A pattern of unscrupulous conduct in certain sectors of low-wage staffing industry exists statewide. Reports from community organizers, legal complaints brought by state agencies, press reports and focus group research conducted among the lowwage temp workforce paint a picture of law breaking in a wide-range of workplaces in all parts of Massachusetts.

\section{Springfield: $\quad$ Temps and the Attorney General Challenge Wage Violations at Labor Ready}

As for back as 2001, an organizing campaign initiated by the Springfield-based, AntiDisplacement Project (now the Alliance to Develop Power) resulted in the Massachusetts Attorney General's Office taking action to stop wage violations by one of the nation's largest temporary help agencies, Labor Ready Northeast. Labor Ready, ${ }^{37}$ whose staffing agency offices throughout Massachusetts deploy thousands of low-wage temps, has been cited for numerous wage and hour violations in other states. ${ }^{38}$

Temp workers hired by Labor Ready reported a series of wage and hour violations to ADP organizers. Temp workers complained that Labor Ready did not pay them for mandatory work that extended beyond the 8-hour workday. In addition, temps were each charged a daily fee of between four and ten dollars to ride to work in overcrowded vans. Women workers were not provided bathrooms at construction sites where they were sent to work. ${ }^{39}$ To add insult to legal injury, sometimes workers experienced up to five hours of unpaid wait time resulting from late-toarrive temp agency transportation.

Ultimately, the Massachusetts Attorney General charged Labor Ready with illegally profiting from requiring its temp workforce to cash paychecks at the company's cash machines, costing workers up to two dollars for each check cashed. In 2006, Labor Ready agreed to pay $\$ 250,000$ in back wages and penalties for wage violations and for charging workers mandatory fees to cash paychecks. ${ }^{40}$

The Springfield temp worker experience is consistent with the reports the Massachusetts Coalition on Safety and Health (MassCOSH) gathered recently while conducting focus group research among temp workers in five cities in eastern Massachusetts. Two-thirds of the temp workers she interviewed reported that basic information about overtime, wage rates or deductions from wages for special work gear was not provided by the temp agencies that employed them. ${ }^{41}$ 


\section{Streetcorner Temping in Chelsea}

Ten years after settlement of the Springfield Labor Ready case, the temp worker experience in Chelsea, Massachusetts, home to more than 14,0000 Central Americans, indicates that wage theft remains a chronic problem. The Chelsea Collaborative, a community-based civil rights and immigrant advocacy organization has documented the abuses, fear and retaliation experienced by this workforce.

Chelsea temps report theft, health and safety violations, and crass forms of sexual harassment to the Chelsea Collaborative staff organizers, Yessenia Alfaro and Maria Alvarez. Of particular note is a Chelsea temporary staffing company that shuttles hundreds of immigrant temps each day to abusive workplaces throughout Massachusetts and southern New Hampshire.

On any given morning - as early as 4 a.m. - hundreds of immigrant temp workers can be found gathering at primitive shape-ups on street corners in Chelsea or East Boston waiting for unmarked, temp agency vans. Unlike the street corner "day laborers" or jornaleros prevalent in many large urban areas, ${ }^{42}$ these Chelsea workers are not soliciting work directly with small business owners or building contractors. These workers are temp agency employees, directed to begin their 12 hour workdays waiting for the temp agency van to shuttle them to substandard janitorial jobs, fish markets, bakeries, packaging outfits and construction sites in Worcester, Woburn, Fall River, New Bedford, and southern New Hampshire.

For these street corner temps, the prospect of paid work is uncertain even when the temp agency orders workers to report to the corner. When the unmarked temp agency van arrives, workers may have to compete for a seat, as the temp agency orders more workers to show up on

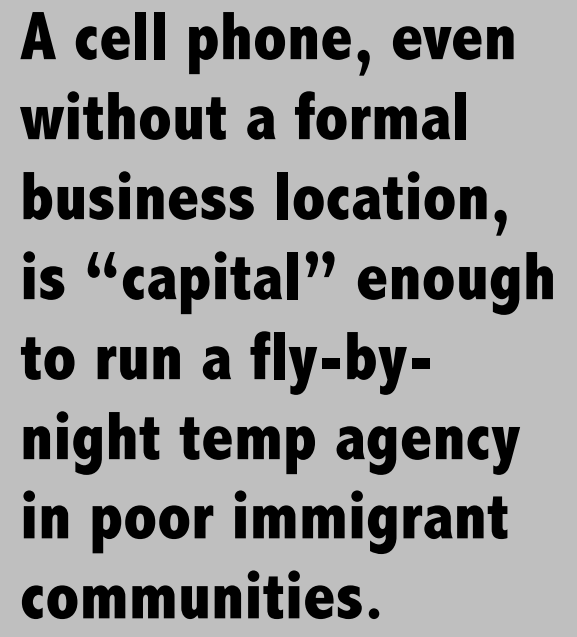
the corner then are needed to fill job orders. Vans designed to seat seven or eight persons are crammed to overcapacity with ten more workers, some seated on the floor, others on the laps of other workers. Jockeying for a seat in the van can involve crude forms of sexual favoritism, whereby the temp agency van driver offers spots to the young women on the corner that he finds most attractive.

Many Chelsea-based temp workers are required to travel to worksites in temp agency vehicles. They receive no compensation for travel time. Rather, they pay for the "privilege" of being trucked to and from worksites by van drivers, often agency supervisors or gang bosses that demand daily in-cash payments for transportation. At the end of a work shift, the agency van can be hours late for the long trip back to the street corner where their workday began. At times, temps are transported far 
from their neighborhood only to be informed by the business client that there is no work that day. These temps are not paid for travel time or the time they wait at the worksite for the van that takes them back to Chelsea with the other temps. ${ }^{43}$

Patricia, a young Salvadoran seeking work, told a typical story that reveals how the Chelsea "fly-by-night" temp agencies operate. ${ }^{44}$ She was referred by a friend to an "oriental man who gave jobs to Latinos" in Chelsea. His "office" was an unmarked storefront where workers gathered on the sidewalk at 5 a.m. When she arrived, she observed workers getting into an unmarked van:

There was no logo or company's name around or on the van. The oriental man knew a few Spanish words that helped with our communication. He asked for my name, gave me some papers to fill out with my basic information such as tax papers. He persuaded me to write seven dependents because I would "get pay more money" but he never mentioned how much I was going to earn. Afterwards he told me to get in the van that was crowded, with more than ten people sitting on top of one another. I remembered feeling uncomfortable, sitting on a stranger's lap. I realized that there was not time to ask questions or make complaints. ${ }^{45}$

Patricia was shuttled to a printing company to clean ink-laden machines without a uniform or any protective equipment. Some days, she waited in the cold for more than four hours before the entire work crew gathered and the van came to return them to Chelsea. She was charged $\$ 35$ a week for this transportation and was not given her check until she paid cash for the rides. ${ }^{46}$

Many types of wage scams are used to defraud temp workers. Patently illegal 'ofthe-clock' violations are common. Temps are directed to start working long before they 'punch in' and are ordered to continue work after a supervisor 'punches' them out. During the lead-up to busy holiday seasons, when overtime work is common, wage theft can be even more brazen; Chelsea temps report having worked as many as 100 hours and then received paychecks for only 40 hours of work. ${ }^{47}$

Wage theft, denial of workers' compensation coverage and job discrimination are all exacerbated by language barriers and low levels of literacy. Alfaro indicates that another major difficulty the Collaborative faces when providing assistance is that workers are not given any record of the hours worked and they do not know the name of the employer's business or the location where they worked. "All the workers know is that a van will pick them up in front of the building at 6 a.m." 48 


\section{Underground Temping: Framingham and Central Massachusetts}

In the Boston suburbs adjacent to the I-495 corridor, an immigrant staffing agency workforce labors in restaurants, construction, food processing facilities, and granite finishing factories. These workers, mostly Brazilian, Guatemalan and Ecuadorian, do not find work at well-known staffing agencies like Labor Ready. Rather, as Diego Low, Coordinator of the Framingham-based Metro West Worker Center, explains, these workers are employed by marginal, underground staffing agencies.

According to Mr. Low, ${ }^{49}$ major employers use these staffing agencies to "offshore their legal responsibilities." This creates a complicated, often impossible, situation for temp workers when they attempt to initiate legal action to recover unpaid wages. In 2006, for example, a labor dispute at a nationally known, organic food processing company in the Framingham area brought to public attention how this employer used a marginal staffing agency, operating behind the scenes, to avoid its legal obligations. At least 70 of the company's workers were on the payroll of a temporary staffing agency that played virtually no role in hiring, training or supervising the workers. The agency's only function was to drop off paychecks at the factory.

Following a work stoppage by its largely immigrant workforce, the food processing company decided to close the plant, suddenly announcing and carrying out a massive lay-off. The company was accused of violating its obligations to employees under the WARN Act, 50 which requires employers to provide advance notice of mass layoffs involving 50 or more workers. The food processing company responded that it had not violated the WARN Act because $85 \%$ of its long-term employees were supplied by two staffing agencies. The employer was able to use the temporary staffing agencies as a shield to avoid a legal obligation to notify its workforce that a major layoff was pending.

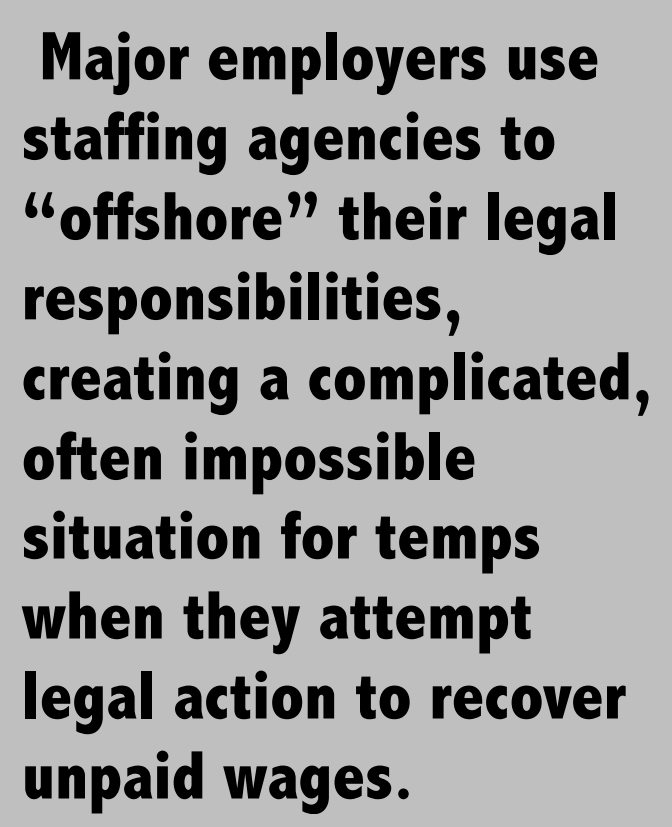

More recently, in the summer of 2010, the Natick location of a popular high-end restaurant chain became the subject of a wage and hour investigation by the Attorney General's Office for refusing to pay its Latino kitchen staff overtime and earned wages. The restaurant claimed that it would pay the owed wages and overtime - one month late - once the restaurant closed its doors for good, dangling the hope of payment to hold the immigrant workforce hostage. Upon investigation, it turned out that a staffing agency was actually issuing paychecks, even though the workers were never informed that they were employed by a staffing agency. That 
agency has since closed its doors without paying owed wages and overtime. A delegation from the Metro West Worker Center was able to secure some of the unpaid back wages. However, the temporary agency and the restaurant are being investigated by the U.S. Department of Labor. ${ }^{51}$

Moving west towards Worcester, in 2009, following an investigation by the Joint Enforcement Task Force, Attorney General Martha Coakley brought a complaint against a quasi-underground temporary staffing agency, Labor Solutions, Inc. The temp agency owner was charged with willful failure to pay overtime, willful failure to provide a pay stub, workers' compensation insurance fraud, and unemployment insurance fraud. The business provided temps to light industrial firms in the Worcester area, and operated primarily on a cash-based payment system. Many temp workers did not receive pay stubs and were paid more than a dollar below minimum wage. The owner pleaded guilty to 65 counts of violating state wage and hour laws, including failing to pay the state minimum wage to hundreds of temp workers. He was ordered to pay $\$ 500,000$ in restitution and serve five years probation. ${ }^{52}$

Staffing agencies are also at the center of a wage and hour class action filed in 2010 against a Worcester stone cutting company. Here, a scheme involving "checksplitting" among multiple staffing agencies cost immigrant workers earned overtime pay. For a 70-hour work-week, workers received two paychecks from two different "employers", each of which issued a check for less than 40 hours pay. This chicanery allowed the company to employ staffing agency workers for as many as 70 hours a week, but avoid overtime rates required by federal law. Under the "check-splitting" scam no overtime was paid or reported because, ostensibly, the workers were employed for no more than 40 hours a week by each "employer."53 A similar illegal scheme was reported by Chelsea area temps to cheat workers out of overtime pay.

The IWCC is speaking out against the growing practice of outsourcing jobs to temporary agencies as a means of facilitating violations of labor standards. As Carlos Rosales, Coordinator of IWCC, puts it: "The absolute lack of regulation of these shadowy organizations allows unscrupulous employers to engage in a shell game of wage violations. We need stronger laws to regulate these employment agencies."54

Wage theft using triangular staffing arrangements is also prevalent in the construction industry. Mike Rabourn, Research Specialist for the New England Regional Council of Carpenters, summarized the problem: "In the construction industry, temporary employment agencies have a decidedly negative impact on job quality, safety standards, and equal access to employment. These agencies act as a buffer between building contractors and regulators, obscuring accountability and stifling enforcement." 55 


\section{B. Temp Stories: Health and Safety Laws: A Failed Health and Safety System for the Low-Wage Temporary Workforce}

A review of OSHA citations, interviews with lawyers, worker center staff, and reports and testimony from temp workers, indicate a pattern of health and safety problems for low-wage temps in a wide array of industries. In 2009, MassCOSH, conducted focus group comprised of temp workers in five Massachusetts cities. Isabel Lopez, Worker Center Coordinator for MassCOSH, reports that low-wage temporary workers face elevated risk of occupational injuries and illnesses than standard employees. ${ }^{56}$ This is, in significant part, due to the lack of information about safety conditions provided by temp agencies when they make assignments, and the lack of training, proper gear and safety equipment at worksites. Ms. Lopez summarizes the scope of the health and safety problems that her watchdog agency has documented as follows:

Workers told us about the hazardous conditions they face at worksites. We spoke to temp workers who suffered eye injuries and respiratory problems, others who were exposed to asbestos and one whose coworkers was hit by a forklift because the operator had been put to work without training. These workers had difficulty obtaining medical treatment because they were unaware of who was the temporary agency's workers' compensation provider, or even if the agency had purchased workers' comp. ${ }^{57}$

The response one temp worker employed in warehouse and loading work during a focus group in Lawrence mirrored what many others at these focus groups said was at the core of their problem - a lack of basic information about their employment.

The worker explained that a lack of information was often implicated in safety problems and workplace injuries:

The working conditions and hazards on the job while working at the port unloading ships were horrible," reported on temporary worker. "We had to work with sharp machines and cut boxes with sharp knives. There were hazards with contaminated merchandise coming from overseas. Protective equipment was never provided or masks to protect us from the dust inside the ships." Another temp worker employed in warehouse and loading work explained the dilemma that arises when a workplace injury does occur. "Many of us do not know where they are taking us to work, they only tell us that we have to have a ride to get to the workplaces. Therefore, we do not know if we had a complaint where to go, since if we work for one day we do not know where we worked. ${ }^{58}$ 
New Bedford: Safety and Health Problems in the Waste Recycling Industry

The extent of the health and safety problems experienced by low-wage temp workers in Massachusetts is well illustrated by the plight of temp workers in the New Bedford area. ${ }^{59}$ In this part of Massachusetts, temps are often employed in fish processing and waste recycling, two industries with a documented and problematic safety record.

Low-wage temp workers make minimum wage performing essential tasks at recycling facilities in southeast Massachusetts. They routinely work without necessary safety equipment or training. In the last five years, ten Massachusetts recycling companies received OSHA citations for more than sixty-five violations. MassCOSH reports that these types of problems correlate with the absence of adequate information about the type of work temps are assigned to perform. This results in a pattern of health and safety problems for temps working at recycling companies.

Jose Lopez said that he was not advised that he would be handling hazardous and unsanitary refuse materials until he arrived for temp work at a recycling plant. Only then did coworkers inform him that vaccinations were required 60 to protect him from disease. He was not provided with protective equipment to shield him from toxic odors and chemicals by the temp agency or the recycling plant. Some of Mr. Lopez's coworkers, also temps, became sick from this work. Because they were hired over the phone and did not have the address of the temp agency, they did not know with whom to file a workers' compensation claim with or where to go to file it. ${ }^{61}$

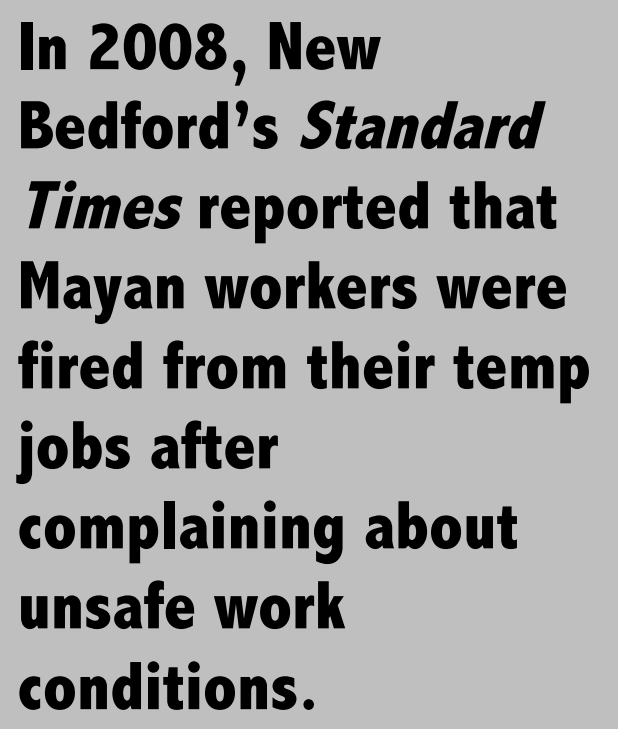

John Argueta reports that during his two-year stint permatemping at a Boston recycling facility, he was not provided with information on the hazards of the recycling industry or proper training needed to safely do his job. Like Lopez, Argueta was not informed that he should be vaccinated or that workers directly employed by the recycling company underwent routine medical examinations to make sure they did not suffer adverse health affects from exposure to workplace toxins. ${ }^{62}$

The safety issues temps face in the recycling industry can be life threatening. In 2009 , a chemical release at a major recycling and disposal center that contracted with the City of New Bedford sent 117 workers to the hospital. ${ }^{63}$ The vast majority 
were Mayan immigrants, farmed out to a recycling center by a temp agency. This incident occurred during a six-month period when, nationally, seven recycling workers died on the job.

New Bedford: Safety Violations Temping in the Fish Processing Industry

Temps employed in fish processing report similar safety problems. There has been a dramatic rise in the use of temp workers in the Massachusetts fish processing industry, where an overwhelmingly immigrant Central American workforce earns the state minimum wage, only a dollar an hour higher than the average wage that was paid for this work 30 years ago.64 Corinn Williams, Executive Director of the Community Economic Development Center of New Bedford, reports that in this industry, "legitimate' businesses" often provide a front for illegal, behind-the-scenes temp agencies that take advantage of the immigration status of many of workers forced to temp in sweatshop conditions. ${ }^{65}$

Yessenia Alfaro, of the Chelsea Collaborative, reports that temps working in fish processing complain that they are not provided with their client firm's personnel policies that directly affect their health and safety. Consider the story of Mirna Hernandez, a Boston-area temp. ${ }^{66}$ She was taken by van to a fish-processing facility and assigned to work in a refrigerated unit of the plant without being advised that she would need to dress in warm layers to do the job. Hernandez was not provided with insulated work clothes or waterproof shoes, both essential to job safety. When her clothing became soaked as a result of a fall into a puddle on the floor, she was refused a change of clothes and fired.

Other temps working in fish processing report not being provided with safety glasses necessary to keep fish blood out of their eyes. Others report having to purchase knives and protective gloves, both necessary equipment when filleting fish. When work assignments are over, temp workers often receive cash payments accompanied by handwritten receipts listing deductions for safety equipment and uniforms.

\section{Workers' Compensation: Not Working for Low-Wage Temp Workers}

Job safety for temps is further compromised by a workers' compensation insurance system that was not designed to accommodate the blurred lines of accountability inherent in triangular employment relationships. Indeed, the U.S. Government Accounting Office (GAO) has concluded that an important factor contributing to lowwage temp workers' vulnerability to workplace hazards is the lack of clearly defined obligations as to who is responsible for workplace safety. ${ }^{67}$ This confusion extends even to OSHA officials who are not sure whether the temp agency or the client employer should be cited for violations. ${ }^{68}$ Not surprisingly, some unscrupulous temp agencies and their client employers work to exploit this legal ambiguity, leaving temp workers completely unprotected and exposed to heightened risk of workplace injury. ${ }^{69}$ 
Receiving workers compensation benefits to cover medical treatment or lost time at work is problematic and uncommon among low-wage temps in Massachusetts. Though the law explicitly holds the temp agency responsible for carrying workers' compensation insurance for the workers it sends out, reports from temp workers indicate that temp agencies in the low-wage sector commonly obscure this fact, and fail to inform temp workers about how and where to file a claim. Disreputable client employers eager to avoid OSHA violations and the costs of workplace safety also vigorously suppress reports of workplace injuries.

When injuries occur, temp agency managers and worksite supervisors threaten workers with retaliation (i.e., termination, blacklisting, or calling immigration authorities) if they try to file a workers' compensation claim. A 2008 expose in The Standard Times, a New Bedford area newspaper, reporting that Mayan temp workers were fired from their jobs with a temporary agency after complaining about unsafe work conditions, is all too typical. ${ }^{70}$ When an injury cannot easily be ignored, workers may even be "dumped" by employers at hospital emergency rooms (with instructions to conceal where the injury occurred), passing the bill for on-the-job injury to taxpayers and hospitals. Tracking the responsible party and holding them liable for these costs is often difficult when temp workers are provided little or no information about their employers or the temp agencies they work for.

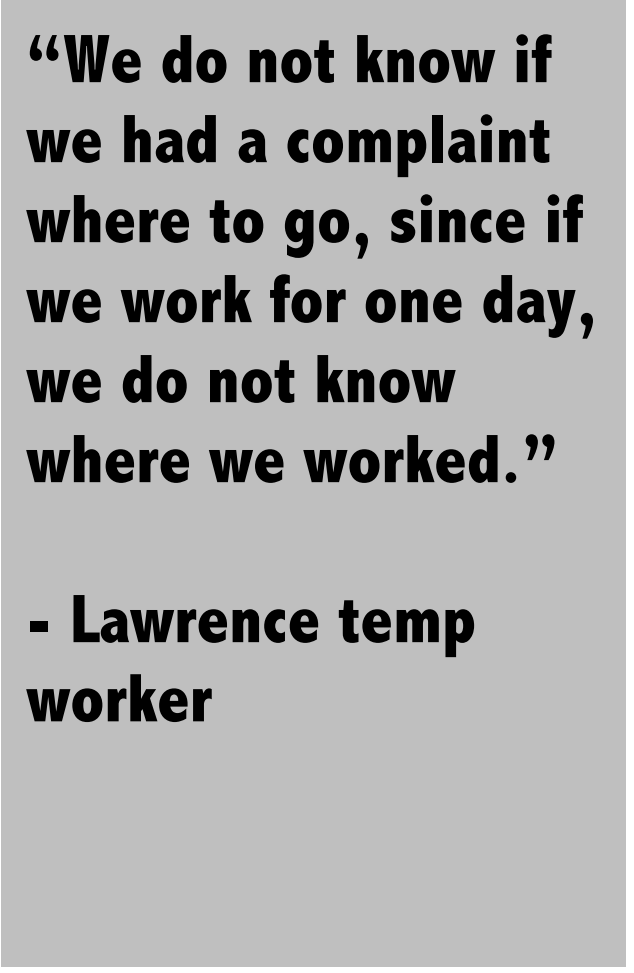

The workers compensation system is further undermined by the fact that the temp agency, which is the insurance carrier, is not on the jobsite to monitor safety standards. When the costs of worker's compensation insurance are borne by outside temp agencies, workplace employers are not motivated to improve safety conditions, or to provide safety training or protective equipment. Attorney Len Schneider, who has represented temps in Massachusetts worker's compensation proceedings, observes that temp agency client employers have sometimes refused to allow temp workers to return to their workplace if the workers were injured on the job, even when the temp agency recalls the temp to active employment. Schneider sums up the attitude of many firms that use temp staffing agencies, by explaining that injured temps workers are often treated "like Kleenex," disposable when used up. ${ }^{71}$

To make matters worse, the Massachusetts Appeals Court has ruled that a temp agency's client employer is immune from third party negligence claims against the 
business by an injured temp worker. ${ }^{72}$ By helping to deflect workers' complaints about safety conditions and suppress compensation claims, temp agencies serve to insulate client employers from liability for workplace safety, and shelter them from rising insurance premiums, even though it is client employers who are in most cases entirely responsible for working conditions and compliance with OSHA standards at the jobsite..$^{73}$

Improving Safety for Temps Requires Clarifying the Obligations of Temp Agencies and Client Employers

If safety for low-wage temps is to improve, temporary staffing agencies must take responsibility for informing temps about safety conditions at the worksite to which they are being sent, and about the gear and equipment that may be needed. In order to repair the regulatory framework, the U.S. GAO explains, temp agencies must be identified, and data about their functioning must become accessible. A "centralized source of information clarifying the role of temporary staffing

The U.S. GAO concluded that an important factor contributing to low-wage temp workers' vulnerability to workplace hazards is the lack of clarity as to who is responsible for safety on the job. agencies and client employers could allow OSHA to more uniformly apply the law," and allow both temp agencies and client employers to fulfill their responsibilities to the public and the low-wage temporary workforce. ${ }^{74} \mathrm{Or}$, as one union researcher that focuses on construction industry trends urged, "[a]ny steps taken to modify the negative behaviors and effects of temp agencies, through increased regulation and enforcement, would be an encouraging and welcome change."75

C. Temp Stories: How Unemployment Law Denies Temp Workers Benefits and Turns Jobseekers into Unwilling Permatemps

Most low-wage workers employed by temporary staffing agencies would prefer stable, permanent work to support themselves and their families. ${ }^{76}$ Unfortunately, state unemployment insurance (UI) law undermines their aspirations by penalizing workers who take temporary staffing jobs to earn some money while they continue to look for full-time, secure employment.

The current UI laws deters temps from finding permanent and suitable fulltime work by assuming that a temp worker who completes a work assignment has "voluntarily quit" his/her job, thus making him or her ineligible for unemployment insurance. ${ }^{77}$ Before temp workers can collect UI or gain access to state-sponsored 
job training they must prove that they sought and were denied a reassignment by the temporary agency. No other categories of workers are subject to this disfavored treatment in the unemployment system.

The case of Thomas K. illustrates the problem. Several years ago, Thomas worked for a temporary agency, reporting for a work assignment daily at 8:30 A.M.78 Usually, he would deliver sheet rock to constructions sites. Thomas would have preferred a permanent job, with benefits, but, initially, this temp job was steady and he stayed on for some time. When work slowed significantly, he asked for more work every day. He stopped at the agency, telephoned and provided his cell phone in case an assignment arose on short notice. But, on most days there was no work for him. He started looking elsewhere for jobs and filed a claim for UI to help to cover his living expenses.

The temp agency challenged Thomas' eligibility for UI, and initially prevailed by denying that he had ever asked for additional work. The law then placed the burden on Thomas to reverse the state's denial of UI. He appealed, waiting weeks without any income. When his appeal was heard, the representative of the temp agency said under oath that Thomas had never asked for additional work. However, Thomas' lawyer produced the cell phone records showing that Thomas had called the agency frequently asking for another assignment. Based on this evidence, Thomas was determined to be eligible for UI.

Temporary employment agencies have significant financial incentives to dissemble about whether a worker sought reassignment or whether work was available when an assignment ends. And, as Thomas K's ordeal illustrates, ${ }^{79}$ temp agencies are easily avoiding their obligations to provide UI benefits by claiming that temp workers 'voluntarily quit.' Temp workers, particularly those that do not have the benefit of free legal services, have a difficult time meeting their burden of proving that a new assignment was not offered to them when the law does not require that temp agencies provide temp workers with written documentation of the length of assignment or the hours worked on any given job. Thomas had a positive outcome because he had a lawyer; most workers would simply be taken advantage of.

At this point, Massachusetts unemployment law provides a virtual guide for how temp agencies can maintain an unwilling workforce of underemployed permatemps and, at the same time, lower their insurance rates at the expense of these workers who would rather find permanent work. ${ }^{80}$ 


\section{LoW-Wage Temps in Massachusetts: A Second-Tier Workforce VULNERABLE TO WAGE THEFT AND UNSAFE WORKPLACE CONDITIONS}

The information gathered in this report provides a disturbing view of the world of non-standard work. The pattern of recurrent violations of the most basic wage and hour laws points to a lawless "black hole" where core workplace laws and standards that we have long considered inviolate do not operate. ${ }^{81}$

The findings presented below identify the major problems confronting the lowwage temporary workforce. The issues we are highlighting are easily remedied. What is needed is the will to enact legal reform to create an effective regulatory scheme that will allow temp workers, their advocates in community based organizations, law-abiding staffing agencies and their business clients to work together to achieve fairness and flexibility in the low-wage temporary staffing industry.

\section{Finding 1: The Low-Wage Temporary Workforce is a Growing, Unregulated Labor Market}

As the evidence presented in this report indicates, the temporary staffing industry will continue to expand in a wide range of low-wage industries and services.

- Temp agency jobs will likely constitute a growing proportion of all new jobs created in the U.S. in coming years.

- Temp agency workers in the low-wage economy are no longer just shortterm replacements. Permatemping is an expanding trend in the low-wage economy. We can anticipate the systematic growth of temporary labor to staff entire job clusters and industries indefinitely. Evidence from warehousing, hotels, food processing and manufacturing all confirm an institutionalization of this no-frills employment paradigm that creates a second-class workforce.

- While workforce flexibility is certainly an upside of temporary employment, economists have concluded that the expanded use of temp workers to meet flexible production and distribution needs has also had a significant downside.

○ temp agency workers earn substantially lower wages than standard employees in the same jobs, and suffer a pervasive absence of workplace benefits, such as health insurance.

- The situation is worst of all for those in the low-wage sector of the industry, where as noted above, the problems are exacerbated by the 
rampant violation of core workplace laws and the high incidence of low-road temporary agencies that thrive in the shadows of the underground economy. Here, health insurance, pensions, and job ladders are non-existent.

- In the low-wage sector, it is an urban myth that temp work provides a path to permanent jobs.

\section{Finding 2: Low-Wage Temps Comprise a Highly Vulnerable Segment of the Workforce Often Laboring in the Underground Economy}

Of particular concern is the fact that unscrupulous employers are drawn to the temporary workforce because it is disproportionately composed of young, immigrant workers and comprised of a high percentage of persons of color. These workers are often less proficient in English and have attained lower education levels compared to workers employed in standard jobs. All of these factors amplify the potential for exploitation in a population whose fundamental work experience is, by definition, precarious. ${ }^{82}$

The unregulated nature of the temporary staffing industry and a general underenforcement of labor laws has normalized a "gloves-off economy" in low-wage labor markets. The impact of this lawless work environment is most problematic in the shadows of the underground economy, where the labor market is peppered with off-the-book temp agencies that routinely deprive temp workers of income they have earned in difficult and dangerous jobs. Marginal businesses and employers with unsafe workplaces often turn to fly-by-night temp operations, subjecting temps to unsafe work conditions without the benefit of safety training, needed protective gear or workers' compensation insurance.

\section{Finding 3: Triangular Employment Relationships Present Unique Challenges for the Enforcement of Wage and Hour Laws in the Low-Wage Economy.}

Temporary staffing agencies in the low-wage sector complicate and undermine the enforcement of basic labor laws, most of which were not enacted with triangulated employment relationships in mind. Client firms that contract with temporary staffing agencies to hire temps often believe that they do not have to answer for violations of workplace standards because workplace law does not consistently define client business as employers of their temporary workforce. Unscrupulous businesses are incentivized to "outsource" their employer obligations to unregulated staffing agencies that often facilitate their efforts to circumvent laws and regulations in a number of areas, including wage and hour, health and safety, workers' compensation, unemployment insurance and payment of payroll taxes. 
As a result, the legal protections most workers take for granted are, in fact, not readily available to the low-wage temp workforce. Recurrent violations of the most basic wage and hour laws in this sector present a patent indicator of temps' weak position in the labor market:

- $\quad$ Temps are often victims of wage theft because they have no means of documenting or verifying the hours they have worked;

- $\quad$ Unscrupulous temp agencies and employers often use temporary employment arrangements to mask wage violations and deny workers earned overtime pay;

- $\quad$ Temp workers are charged fees for transportation and safety equipment that in some cases drives their wages below the legal minimum;

- $\quad$ Temps are required to use and pay for staffing agency transportation, often in violation of Massachusetts laws designed to protect workers from mandatory transportation fees. ${ }^{83}$

\section{Finding 4: Blurred Lines of Employer Responsibility and the Widespread Malfeasance of Low-Road Temporary Agencies and Client Businesses Have Resulted in the Under- Enforcement of Safety Standards for Temp Workers}

The triangular employment relationship associated with temp agency employment has also confounded a system of health and safety laws that were structured to enforce workplace safety in standard two-way employer/employee relationships. ${ }^{84}$ When temporary staffing agencies enter into the picture, temp workers and employers experience some confusion as to who is obligated to provide health and safety training and necessary equipment for low-wage temp workers and for compliance with established federal OSHA and state DOS standards.

The blurred lines of authority and responsibility contribute to the heightened risk of injury that temps experience at the workplace. ${ }^{85}$ This confusion, along with the often willful negligence of temp agencies and their client employers in the low-wage sector, has resulted in a constant series of acts and omissions that contributes to disparate treatment and the second-class status of low-wage staffing agency temps. As it now stands:

- $\quad$ Temp agency employees are less likely to receive personal protective equipment or safety training than workers in standard employment relationships; ${ }^{86}$

- $\quad$ Some temp agencies do not provide temp workers with even the most basic information regarding workplace hazards they 
encounter on their work assignments, or about their rights with respect to workers' compensation;

- $\quad$ Temp agency business clients routinely fail to provide temps with personnel policies that detail safety standards at their workplace; 87

- $\quad$ Temp workers, fearing retaliation and blacklisting, underreport health and safety problems they suffer on the job;

- $\quad$ Client businesses have a reduced incentive to provide temp workers with safety information or equipment because only the temp agency is legally responsible to carry worker's compensation insurance; client businesses are immune from third party negligence suits by temp workers.

In short, temporary staffing relationships are amplifying the health and safety problems that already plague the low-wage workforce. Temps believe, not unrealistically, that corrective actions are unlikely and feel that the risk to their safety is a price to be paid if they want to remain in the pool of temps to be sent to the next job.

\section{Finding 5: Temp Agency Fraud Amounting to Tens of Millions in Lost Revenue Burdens Government and Taxpayers}

A disproportionately high percentage of temporary staffing agencies have been identified as perpetrators of wage and tax fraud, 88 depriving state and federal governments of revenue. In 2010 alone, two Massachusetts staffing agencies were identified as responsible for as much as \$45 millions dollars in unpaid workers' compensation insurance, federal withholding, social security and Medicaid taxes. (

Corrin Williams of the New Bedford Economic Development Council reports a longstanding pattern of the cross-state movement of workers by law-breaking temp agencies involving tax fraud. ${ }^{89}$ For example, in June of 2010, the owner of a Providence, Rhode Island temporary employment agency plead guilty to a host of federal criminal charges arising from the deployment of East Asian, non-English speaking temp workers to more than 30 workplaces in Rhode Island and Massachusetts. The owner was convicted of cheating the federal government out of between $\$ 7$ and 20 million in federal withholding, social security and Medicare taxes. He was ordered to pay more than $\$ 14.3$ million in back payroll taxes for the temp workers he supplied to businesses. ${ }^{90}$ 


\section{Creating FleXibility with Fairness: Amending Employment AgenCy LAW TO PROTECT THE LOW-WAGE TEMP WORKFORCE}

The Massachusetts Employment Agency Law $^{91}$ is in dire need of an update. The statute has not been overhauled or meaningfully amended since 1966. Since then, seismic shifts in technology, workplace culture and labor market expectations have occurred. Notably, during this time, the low-wage temporary staffing business - a marginal business in the 1960s - has grown exponentially, undermining and challenging workplace rights and standards in ways not anticipated by the drafters of the Employment Agency Law.

A series of reforms to modernize employment agency law are needed if we are going to create fairness for the 21st

The Massachusetts

Commission to Investigate Employment Offices found in 1911 that the "fraud, dishonesty and immorality" of some employment agents went undiscovered and unpunished. A century later, these problems have again emerged. century's low-wage temporary staffing workforce while maintaining the flexibility that employers are demanding to keep pace in today's globalized economy. Successful reform requires a law that promotes transparency and the right to know for temp workers. An updated law must contain a meaningful enforcement scheme that can foster a level playing field for all employment agencies, provide decent jobs for temp workers and help build a strong economy that will benefit taxpayers and consumers throughout Massachusetts. In order to do so, the updated law must include four critical changes:

\section{ONE: Eliminate the Double Standard in the Employment Agency Law}

As it now stands, the law neither protects low-wage temp workers from abuses nor effectively serves law-abiding businesses operating in today's fast-moving economic environment. At the core of the problem is a legal double standard resulting from the limited scope of the Employment Agency Law. On the one hand, the law provides an overly-complicated, bureaucratic scheme of licensing and regulation for permanent placement agencies. On the other, there is a complete lack of regulatory oversight for low-wage temporary help services.

This regulatory disparity is all the more troubling because the temporary staffing agency business - the unregulated portion of the employment services industry now comprises well over $70 \%$ of the employment agency business in Massachusetts and elsewhere. ${ }^{92}$ The law must be streamlined to make registration and compliance less onerous for permanent employment agencies and overhauled to include 
protections for the large number of low-wage temp workers that fall outside of the protections in the current law.

We are confronting a labor market crisis not unlike one that existed at the turn of the 20th century when the Massachusetts legislature created a commission to document abuses of workers by employment agencies. The 1911 report of the Massachusetts Commission to Investigate Employment Offices could have been written today. The Commission recognized that the commercial employment agency "is a business in which fraud and imposition are peculiarly possible." The Commission report explained:

The business is one requiring little or no capital, and so may be taken up easily by irresponsible and unscrupulous persons. Persons with whom the employment office keeper deals are ... in many cases so driven by the necessities resulting from unemployment as to be willing to put up with anything if only they can get employment. ... We have, then, a business which may easily be taken up by cheaters, in which the persons to be dealt with are, on the whole, rather easy to cheat, and in which, because of the nature of the business, it is particularly easy to cheat without being detected, and it is for this reason that governmental regulation and supervision are deemed necessary. ${ }^{93}$

A century ago, many employment agency operators remained unlicensed and it was difficult to locate violators for workers seeking restitution. ${ }^{94}$ Overall, the Massachusetts Commission to Investigate Employment Offices found that the "fraud, dishonesty and immorality" practiced by some employment agents usually went undiscovered and unpunished. ${ }^{95}$ Workers lacked the means to bring legal actions, or prove an agent's malfeasance.

This led to state and local laws in the early 20th century that addressed what the U.S. Commission on Industrial Relations concluded was a private employment agency industry that "reeks with fraud, extortion and flagrant abuses of every kind." By 1928, Massachusetts as well as 38 other states, had either enacted or strengthened state and local laws to address the "dangerous temptation of abuse and fraud" in the commercial employment agency business, the clientele of which at that time consisted of the most vulnerable strata of unskilled laborers and recent immigrants. ${ }^{96}$

Today, we are again facing lawlessness in a woefully under-regulated labor market involving the commercial employment agency business. The rapid and explosive growth of the commercial temporary staffing industry is recapitulating workplace abuses not unlike those documented by the Massachusetts Commission to Investigate Employment Offices a century ago. These problems will not be rectified by the operation of free market forces or by informal "codes of ethical conduct" adopted by the industry. There will be no meaningful improvement without 
legislative reform that subjects the low-wage temporary staffing industry to regulation designed to end abuses and close loopholes in the outdated Massachusetts Employment Agency Law. Once again, conditions call for legislative action to protect the temp workforce and improve the competitive position of those agencies and employers that do play by the rules.

\section{Two: Create Transparency and the Right To Know}

There cannot be fairness in the temporary staffing industry when low-wage temp agency workers are denied basic information about their jobs. As it currently stands, the law does not address a fundamental lack of transparency in the employment relationship or the myriad problems it engenders.

Now, temp workers are routinely deployed to client businesses without having basic information about the terms and conditions under which they will be toiling. Information as fundamental as the name of the temporary staffing agency or the location of the work assignment are disguised or withheld. Temp workers often do not learn of their rate of pay until they receive their paychecks. Hidden costs of uniforms, transportation and safety equipment are routinely deducted without advance warning. Wage theft is particularly difficult to identify, let alone remedy. Confusion reigns when a temp has to report a workplace injury or safety problem.

In order to take temp workers out of the dark, there must be a right to know the terms and conditions of work before starting a job assignment. This is the most important information that a temporary staffing worker needs in order to be protected from unscrupulous employment practices. Temporary agencies should therefore provide low-wage temp workers with the following information in writing in a language they are fluent in before having to commit to a work assignment:

- The location and name of the client employer and the temporary staffing agency;

- $\quad$ The rate of pay for each type of job performed and the benefits, if any are to be provided;

- $\quad$ The anticipated length of the work assignment;

- Whether training and safety equipment will be required and who is obligated to provide and pay for it;

- $\quad$ The legal entity responsible for workers' compensation should they be injured on the job; 
- Upon completion of the job, receipts and a paycheck itemizing deductions for costs of transportation, uniforms and/or safety equipment, and detailed information documenting the starting and finishing times and the total number of hours employed;

- Information about how to contact the designated enforcement agency (e.g. the Department of Occupational Safety).

Currently, a temporary staffing agency is not legally required to provide any of this information to its workforce. On the other hand, under the Massachusetts Employment Agency Law, permanent employment agencies that typically place professionals, are legally obligated to furnish applicants with written information on anticipated wages, costs of transportation, fees to be charged and whether the assignment is permanent or temporary. ${ }^{97}$ The same should be required of the temporary staffing agencies employing low-wage workers in non-professional jobs.

\section{THREE: Provide Meaningful Enforcement of Labor Standards for the Temp Workforce}

Enforcement of laws protecting low-wage temps requires pro-active government monitoring and the ability of workers to seek legal redress without fear of retaliation for violations of the law by abusive temp agencies and client employers. Massachusetts has taken significant steps in this regard by establishing the Misclassification Task Force within the Executive Office of Labor and Workforce Development. One aspect of its work has been to identify unscrupulous employers, including temporary staffing and employment agencies that avoid their obligation to pay overtime, collect social security taxes and provide unemployment and workers' compensation insurance.

\section{Compliance Requires Recordkeeping and the Right to Inspect Business Records}

The Task Force, with representatives from labor, business and community-based organizations, has recognized that devoting resources to enforcing workplace standards benefits the entire Commonwealth. However, a meaningful enforcement scheme that roots out unscrupulous practices in the staffing industry is not possible under the existing regulatory scheme. Currently, the law lacks any requirement that temporary staffing agencies keep certain records indicating their compliance with laws that set minimum standards for the operation of temporary staffing agencies. Any reform of the employment agency law must include the ability of the Department of Labor to inspect pertinent records to assure compliance with the law. 


\section{Temp Workers Need an Anti-Retaliation Provision and A Private Right of Action}

Protecting the low-wage temporary workforce also requires a legislative scheme that provides temp workers with a private right of action against those temp agencies and their clients that break the law. Low-wage temp workers -particularly those who labor in the underground economy - fear retaliation and discriminatory treatment if they report wage theft or safety problems to state authorities. For this reason, like the minimum wage and anti-discrimination laws that protect vulnerable workers, legislation intended to protect low-wage temp workers must include a private right of action, an anti-retaliation provision and the right to recover attorney's fees and costs when prevailing on meritorious claims.

\section{The Illinois Example: Legislation Protecting Temp Workers}

Recent legislative reform in Illinois is instructive and merits emulation. The Illinois Day and Temporary Labor Services Act ${ }^{98}$ (DTLSA), enacted in 2001, provides comprehensive protection for temporary staffing workers. In 2010, DTLSA was amended to provide low-wage temporary agency workers with a private action to recover earned, but unpaid wages and overtime pay from abusive staffing agencies and employers.

In the Chicago area, tens of thousands of temporary agency workers make up the core workforce for the logistics industry, comprised of large warehouses owned by major big-box retailers. ${ }^{99}$ A legal services organization, Working Hands Legal Clinic, recently brought suit under DTLSA on behalf of temporary warehouse workers. ${ }^{100}$ The suit seeks damages and injunctive relief, alleging that temp agencies routinely cheated warehouse workers out of earned wages and overtime pay for long, backbreaking days of work to unload shipping containers. Counsel for the temp workers, Chris Williams, staff attorney for Working Hands Legal ${ }^{101}$ Clinic, explains that DTLSA contains two provisions that proved essential to protecting these workers: The legal requirement that billing records, i.e. written documentation of assignment and hours worked be provided to temps, coupled with a private right of action has allowed temp workers to step forward and seek redress for egregious violations of their rights. ${ }^{102}$

Williams explained that DTLSA has "brought much of the industry out of the shadows and under the regulatory auspices of the Illinois Department of Labor." Williams points out that "many of the low road agencies have been driven out of the field. He also explains that "Practices commonplace even among larger, more established staffing agencies-such as "check-splitting" to avoid overtime hours by issuing pay at regular rate on a second check, shorting hours, requiring laborers to work off the clock, complying with discriminatory requests for laborers from companies-have slowly begun to disappear."103

Protecting temp workers' rights in Illinois required legal reform. As Illinois state Senator Miguel del Valle, sponsor of DTLSA, explained, legislative reform resulted 
from the work of community-based organizations and a realization by the temporary staffing industry "that bad apples were messing up the reputation of the industry."104 Massachusetts would do well to follow the lead of Illinois by updating and modernizing its Employment Agency Law.

\section{FoUR: Level the Playing Field for All}

The unchecked and widespread abuse of workplace standards in the low-wage temp agency sector promotes a race to the bottom that undermines efforts to create good jobs and threatens the viability of law abiding temporary staffing agencies and their clients. Workers and business along with the taxpaying public all lose out when workplace laws do not address substandard, sweatshop conditions.

Better enforcement of worker protections is part of the solution but, by itself, will not solve the problem. Reform of the Commonwealth's Employment Agency Law is also necessary to ensure that good jobs are created in Massachusetts as businesses, including law abiding staffing agencies and their employees, work hard to hasten economic recovery and facilitate renewed prosperity for all. 


\section{ENDNOTES}

1 Jacob S. Hacker. The Great Risk Shift: The New Economic Insecurity And The Decline Of The American Dream (2008); Katherine V.W. Stone. From Widgets to Digits: Employment Regulation for the Changing Workplace (2004); Paul Osterman. Securing Prosperity: The American Labor Market: How It Has Changed and What to Do About It (1999).

${ }^{2}$ Louis Uchitelle, The Disposable American (2006); Katherine V.W. Stone, "Legal Protections for Atypical Employees: Employment Law for Workers Without Workplaces and Employees Without Employers." Berkeley Journal of Labor and Employment Law. 27:251 (2006).

3 This is likely a conservative estimate of the low-wage temporary staffing workforce in Massachusetts. See n. 17.

4 Tian Luo, et. al. "The Expanding Role of Temporary Help Services from 1990 to 2008," Monthly Labor Review. August 2010.

5 Mass. Gen. Laws ch. 140, §§ 46A - 46R.

${ }^{6}$ Erin Hatton, The Temp Economy: From Kelly Girls to Permatemps in Postwar America (2010).

7 Luo, et. al. "The Expanding Role of Temporary Help Services." Monthly Labor Review. August 2010.

8 Steven B. Berchem. "Turning Point: Annual Economic Analysis Puzzles Through the Data and Explains the Trends." Staffing Success. Summer 2010. Found at:

www.americanstaffing.net. Because of high turnover rates, the number of individual agency workers over the course of a year is estimated at about 12 million.

9 The surge in temporary employment, typical of economic recoveries, is more pronounced this time. Temporary jobs accounted for just $11 \%$ of the jobs added after the recession ofthe early 1990s. In the gradual recovery between 2002 and 2005 - often called the "jobless" recovery - temp agency employment experienced a sizable upturn, accounting for 20 percent of all private sector job growth. Husna Haq, "Why 'temp' jobs may be new norm," Christian Science Monitor, March 17, 2011; D.M. McGrath, D.M. and L.A. Keister, "The Effect of Temporary Employment on Asset Accumulation Processes," Work \& Occupations. 35:2, 2008. 197; Jamie Peck and Nik Theodore, "Temporary Downturn? Temporary Staffing in the Recession and the Jobless Recovery," Focus, 23:3. 2005. 39, 41.

10 Hatton. The Temp Economy. 1.

11 Luo,, et. al. “The Expanding Role of Temporary Help Services,” 12.

12 Daniel M. O'Sullivan, Massachusetts Legislative Research Council, Private Employment Agencies (1963) 19, 77.. .

13 U.S. Census Bureau, 2008 County Business Patterns (NAICS 56132). Found at:

http://censtats.census.gov/cgi-bin/cbpnaic/cbpdetl.pl .

14 M. Estevão. and S. Lach. "The Evolution of the Demand for Temporary Help Supply Employment in the United States." National Bureau of Economic Research Working Paper 7427 (1999); S. N. Houseman, A. L. Kalleberg, and G. A. Erickcek. "The Role of Temporary Agency Employment in Tight Labor Markets," Industrial and Labor Relations Review 57(2003); M. Dey, S. Houseman, and A. Polivka, "Manufacturers' Outsourcing to Employment Services." Upjohn Institute Staff Working Paper No. 07-132. W.E. Upjohn Institute for Employment Research (2006). In some industries, like warehousing, low-wage temp agency workers comprise as much as 36 per cent of the workforce as a whole. Nik Theodore. "Political Economies of Day Labour: Regulation and Restructuring of Chicago's Contingent Labour Markets." Urban Studies. 40:9 (2003). The terms "blue-collar" or and "day labor" have been used to designate temp agencies specializing in a wide-range of lowwage jobs. See D.J. Reavis. 2010. Catching Out: The Secret World of Day Laborers; D. Kerr and C. Dole. 2005. “Cracking the Temp Trap: Day Laborers' Grievances and Strategies for Change 
in Cleveland, Ohio," Labor Studies Journal 29:4(2005), 87-108; and D. Van Arsdale. 2008. "The Recasualization of Blue-Collar Workers: Industrial Temporary Help Work's Impact on the Working Class." Labor Studies in Working Class History of the Americas, 5:1 (2008) 7599.

15 T. Bartley and W. T. Roberts. "Relational Exploitation: The Informal Organization of Day Labor Agencies." WorkingUSA: The Journal of Labor and Society 9 (2006), 41.

16 Patrick Kilcoyne, U.S. Bureau of Labor Statistics, Occupations in the Temporary Help Services Industry. 2004. Found at: www.bls.gov/oes/2004/may/temp.pdf

17 Using the official data for Massachusetts, we calculate that, conservatively, there were approximately 22,995 low-wage temp agency workers employed daily in Massachusetts in 2008 , and 25,690 in 2007. We begin with the U.S, Census reports that temp agencies in Massachusetts employed an average of 73,400 workers each day in 2007 and 65,700 workers each day in 2008 (the year marking the start of the Great Recession during which temp agency employment declined significantly nationwide). Our estimate that low-wage industrial and service jobs account for about $35 \%$ of total employment in the temporary staffing industry is further informed by data from the Bureau of Labor Statistics, see Patrick Kilcoyne 2004. Occupations in the Temporary Help Services Industry, BLS. Found at: www.bls.gov/oes/2004/may/temp.pdf, and the American Staffing Association. Consider that the American Staffing Association estimates that its "industrial" sector makes up over $35 \%$ of the temp and staffing industry as a whole, but that low-wage temp assignments are also commonly handled in the "clerical" sector of the temporary staffing industry. We also view these figures as conservative, since, based on the field observations of worker centers consulted for this study, significant numbers of temporary agencies operating in the underground economy are not captured in official statistics.

Note: These figures do not include workers classified as "day laborers" or jorneleros. In this paper, we are not using the term "day labor" in its other common usage, to refer to jorneleros, workers, often hired on streetcorners or informal hiring sites, who bargain directly with small contractors and do not sign up for jobs through temporary staffing agencies.

18 The term "contingent" work, also sometimes termed "nonstandard" employment, has been used to point to several groups of workers whose employment is characterized by indefinite duration and the lack of employer-sponsored benefits, including independent contractors, on-call workers, temporary agency workers, workers provided by contract firms, and (sometimes) part-time workers. See "Contingent and Alternative Employment Arrangements," BLS News, Feb. 2005. U.S. General Accounting Office. Found at: http://www.bls.gov/news.release/conemp.nr0.htm;

${ }_{19}$ See Contingent and Alternative Employment Arrangements, Bureau of Labor Statistics News, Feb. 2005 http://www.bls.gov/news.release/conemp.nr0.htm; U.S. General Accounting Office. Contingent Workers: Incomes and Benefits Lag Behind Those of Rest of Workforce. Report to the Honorable Edward M. Kennedy and the Honorable Robert G. Torricelli, U.S. Senate. GAO/HEHS-00-7 Washington: June 2000; C. Benner, L. Leete and M. Pastor, Staircases or Treadmills: Labor Market Intermediaries and Economic Opportunity in a Changing Economy (New York: Russell Sage Foundation, 2007); Anne E. Polivka, Sharon R. Cohany and Steven Hipple, "Definition, Composition, and Economic Consequences of the Nonstandard Workforce," in Francoise Carre et al. (eds.), Nonstandard Work: The Nature and Challenge of Changing Employment Arrangements (Industrial Relations Research Association Series, 2000).;Belman and Golden, Nonstandard and Contingent Employment: Contrast by Job Type, Industry and Occupation in Nonstandard Work supra note 2, at 206); Kalleberg, Arne, Barbara Reskin, and Ken Hudson, "Bad Jobs in America: Standard and Non- 
Standard Employment Relations and Job Quality in the United States," American Sociological Review 65 (2000); Arne L. Kalleberg, et al., "Externalizing Employment: Flexible Staffing Arrangements in US Organizations," Social Science Research 32 (2003). Temp workers' pay is also considerably lower than that of traditional employees in the same jobs. See Patrick Kilcoyne, Occupations in the Temporary Help Services Industry, Bureau of Labor Statistics, 2004. Found at: www.bls.gov/oes/2004/may/temp.pdf.

${ }^{20}$ Consider that among the temporary workforce as a whole, $17 \%$ of temp agency workers had less than a high school diploma, compared to $9 \%$ of workers in traditional arrangements.. And workers between 16 and 24 years of age, temps are more than twice as likely to have dropped out of high school than those in traditional arrangements. See BLS News, Feb. 2005. U.S. General Accounting Office. Found at: http://www.bls.gov/news.release/conemp.nr0.htm.

${ }^{21}$ Notably, almost half of the temporary staffing agency workforce is either Black $(22.7 \%)$, Asian (5.2\%) or Hispanic (21\%). Id.

22 See n. 14.

23 The proportion of minority workers is even higher for temps working in the low- wage sector. While statistics are not available and data is difficult to come by, all other evidence points to an increasing use of easily exploited undocumented workers unscrupulous temporary staffing agencies. See U.S. General Accounting Office (GAO), Worker Protection: Labor's Efforts to Enforce Protections for Day Laborers Could Benefit from Better Data and Guidance: Report to the Honorable Luis V. Gutierrez, House of Representatives. GA0-02-925. (2002). 10-11 and accompanying footnotes.

${ }^{24}$ M. Vidal and L. M. Tigges. 2009. "Temporary Employment and Strategic Staffing in the Manufacturing Sector." Industrial Relations, 48:1 (Jan), 55-72.

25 Nik Theodore and Jamie Peck. 2002. "The Temporary Staffing Industry: Growth Imperatives and Limits to Contingency." Economic Geography, 78:4, 471.

${ }_{26}$ See, e.g., J. Peck and N. Theodore, "Contingent Chicago: Restructuring the Spaces of Temporary Labor," International Journal of Urban and Regional Research 25 (2001).

${ }^{27} \mathrm{~A}$ recent survey of over 300 low-wage warehouse temp workers in the Chicago area indicated that $96 \%$ favored direct employment over temporary employment. Three per cent of the workers did not answer the survey; only one percent of the workers preferred temp work through a staffing agency. Warehouse Workers for Justice, Bad Jobs in Goods Movement: Warehouse Work in Will County, IL. (2010). Found at: www.warehouseworkers.org.

${ }^{28}$ David H. Autor and Susan N. Houseman, "Do Temporary-Help Jobs Improve Labor Market Outcomes for Low-Skilled Workers? Evidence from 'Work First,"' American Economic Journal: Applied Economics, 2:3 (2009).

${ }^{29}$ See Annette Bernhardt, et al., Unregulated Work in the Global City: Employment Law Violations in New York City. Brennan Center for Justice (2007), 24-25.

30 Id.

31 Id.

32 Establishing a Joint Enforcment Task Force on the Underground Economy and Employee Misclassification. Executive Order 499, Governor Deval Patrick.

${ }^{33}$ See George Noel \& Drew Cahill. 2010 Annual Report, Joint Enforcement Task Force on the Underground Economy and Employee Misclassification. Found at: http://www.mass.gov/Elwd/docs/dia/task_force/ar_2010.pdf

34 Id.

35 Id. 9.

36 Mass. Gen. Laws ch. 140, §§ 46A - 46R. 
37 Labor Ready renamed itself TrueBlue, Inc. in 2007.

${ }^{38}$ See, e.g. David Borgen, "Yarbrough v. Labor Ready: class Action to Enforce California Wage Laws," California Labor \& Employment Quarterly, 16:3, May 2002; "Arizona sues Labor Ready over check-cashing fees," Puget Sound Business Journal, July 15, 2002; "Labor Ready Sued for Charging Workers to Cash Checks," Staffing Industry Report, 13:14, July 26, 2002." ${ }^{39}$ Nancy Gonter, "Temporary Workers Hold Protests," Union-News, B2, Oct. 2, 2002.

40 Chris Reidy, "Temp Agency Agrees to Pay; \$250,000 in Back Wages," Boston Globe, F2, Jan. 13, 2006.

41 See MassCOSH focus group reports. On file with authors.

42 See, e.g., A. Valenzuela, "Day Labor Work," American Sociological Review 29 (2003).

43 Wait time is a problematic issue for the temporary staffing workforce even when this adds hours to the length of the workday, as federal law does not consider waiting for a job assignment at a temporary staffing agency compensable. See Worker Protection. 2002. GAO. 24. Notably, even when temp workers are sent home from the job site without work, service contracts that temp agencies have with their client firms nonetheless provide that the client firm will be billed for a minimum of four hours.

44 Testimony of Yessenia Alfaro to the Massachusetts Joint Committee on Labor and Workforce Development (Oct. 28, 2009).

45 MassCOSH focus group interviews. On file with authors.

46 Id.

47 MassCOSH focus group interviews. On file with authors.

48 Alfaro Testimony. 2009.

${ }^{49}$ This segment of the report is based largely on interviews with Diego Low. May 10. 2011. On file with authors. The IWCC serves as a learning and resource network for immigrant worker centers, helping to build cross-ethnic solidarity and develop collective campaigns for worker rights. IWCC's current member organizations include the Centro Comunitario de Trabajadores (CCT), Chinese Progressive Association (CPA), Massachusetts Coalition for Occupational Safety and Health Worker Center (MassCOSH), and the Metrowest Worker Center/Casa do Trabajador (MWC).

5029 U.S.C. § 2101, et seq.

51 Interview with Diego Low.

52 “Attorney General Martha Coakley's Office Announces Indictments Against Worcester Company and Owner for Wage Violations, Insurance Fraud and Tax Fraud." Press Release, September 23, 2009; “AG Coakley's Fair Labor Division Recovered Over \$8 Million in Restitution and Penalties From Wage \& Hour Violations in 2010." Press Release, January 27, 2011. Found at:

www.mass.gov $/$ ?pageID $=$ cagopressrelease $\& \mathrm{~L}=1 \& \mathrm{~L} 0=$ Home $\&$ sid $=$ Cago $\& \mathrm{~b}=$ pressrelease $\& \mathrm{f}=$ 2011_01_27_fair_labor_recoveries\&csid=Cago.

53 Interview with Diego Low; Complaint filed in Mutz v. Discover Marble and Granite, Inc., et al., C.A. No. --, Worcester Superior Court, March 22, 2011; Communication with Attorney Tod A. Cochran. On file with authors.

54 Interview with Carlos Rosales, by Diego Low, March, 2011. On file with authors.

55 Interview with Mike Rabourn, Research Specialist, Northeast Regional Council of Carpenters. March 8, 2011. On file with authors. .

56 Testimony of Isabel Lopez, Director of Organizing, MassCOSH to the Massachusetts Joint Committee on Labor and Workforce Development (October 28, 2009).

57 Id.

${ }^{58}$ MassCOSH focus group interview, Lawrence, Massachusetts. On file with authors. 
59 Temps from the New Bedford area who experience safety hazards are also victims of wage theft. In this area, where industrial companies are heavily reliant on temp agency labor, temps report that landscaping or fish packing jobs often requires them to work fortyeight hours a week, but that they are only paid for 40 hours of work and overtime is not provided. Testimony of Adrian Ventura, October 28, 2009.

60 OSHA Standards Letter, DOL, Jan. 2, 2003. Found at:

www.osha.gov/pls/oshaweb/owadisp.show_document?p_id=24375\&p_table=INTERPRETA TIONS.

61 Testimony of Jose Lopez to Massachusetts Joint Committee on Labor and Workforce Development (October, 28, 2009).

62 John Aguerta, Testimony to the Underground Economy Task Force. On file with author ${ }^{63}$ See, e.g., "New Bedford chemical leak sends 100-plus to hospitals," Associated Press \& Taunton Daily Gazette, Aug. 3, 2009. Found at: www.tauntongazette.com/news/x804162819/New-Bedford-chemical-leak-sends-100plus-to-hospitals.

64 Joel Dirlam, Daniel Georgianna, Ralph Townsend, Corinn Williams. 2006. Fresh Ground and Herring Processing in New England Final Report. Cooperative Marine Education and Research. 33.

65 Interview with Corinn Williams, Executive Director, community Economic Development, March 15, 2011. On file with authors.

66 Testimony of Mirna Hernandez to the Massachusetts Joint Committee on Labor and Workforce Development (October 28, 2009).

67 U.S. GAO, Worker Protection, 22-3.

${ }^{68} \mathrm{Id}$.

${ }^{69}$ See Id.

70 Jack Spillane, “Immigrants' Advocates Speaking Up More, But Pitfalls Abound," The Standard Times, Nov. 10, 2008.

${ }^{71}$ Interview with Attorney Len Schneider, March 13, $2010 .$.

72 Fleming v. Shaheen Brothers, 71 Mass. App. Ct. 223 (2008) (applying workers' compensation bar to preclude temp worker's negligence claim for on the job injury against client employer as it was held to be the temps' employer under a right to control test.) ${ }^{73}$ Chirag Mehta and Nik Theodore,. "Workplace Safety in Atlanta's Construction Industry," Working USA: A Journal of Labor and Society. 9:1 (2006). Union representatives in the construction arena have also alleged that temp agencies misclassify industrial temps as office workers to lower their insurance rates, cheating the state out of proper workers' compensation premiums.

74 U.S. GAO, Worker Protection,.. 22.

75 Interview with Mike Rabourn. March 8, 2011.

76 Warehouse Workers for Justice. Bad Jobs.

77 Mass. Gen. Laws ch. 151A, § 25(e).

78 The testimony of Thomas K. is on file with the Massachusetts Joint Committee on Labor and Workforce Development in support of the 2009/2010 House Bill 1833.

79 Thomas K's case is by no means unique. See, e.g., Testimony of Stacia Garner and Aretha Harris, before the Joint Committee on Labor and Workforce Development in support of House 1865 and Senate 698, § 5; House 1833; and Senate 698, 12/2/2009.

80 See also Chirag Mehta and Nik Theodore. "Paying the Price for Flexibility Unemployment Insurance and the Temporary Staffing Industry." Working USA: A Journal of Labor and Society. 6:1 (Winter 2002). 
81 See Stephen Befort, "Revisiting the Black Hole of Workplace Reuglation: A Historical and Comparative Perspective on Contingent Work," Berkeley Journal of Employment and Labor Law, 24:153 (2003).

82 See the section of this report entitled "The Demographics of a Vulnerable Workforce." 83 Mass. Gen. Laws ch. 149, §159C (b): If a staffing agency or work site employer or a person acting directly or indirectly in either's interest offers transportation services to an employee and charges a fee for such services, the staffing agency or work site employer shall charge such employee no more than the actual cost to transport such employee to or from the designated work site. The fee, if any, to cover the transportation service costs for each such employee shall not exceed 3 per cent of such employee's total daily wages, and shall not reduce the employee's total daily wages below the minimum wage earned for the day. If a staffing agency or work site employer or a person acting directly or indirectly in either's interest requires the use of such transportation services, no fee may be charged. (c) No staffing agency or work site employer or a person acting directly or indirectly in either's interest may deduct the costs for transportation services from the wages of an employee without the express written authorization of the employee. A staffing agency or work site employer shall furnish to the employee a copy of the signed authorization in a language that the employee can understand. (d) Whoever violates this section shall be punished or shall be subject to a civil citation or order as provided in section 27C.

${ }^{84}$ See C. Mehta, Workplace Safety in Atlanta's Construction Industry: Institutional Failure in Temporary Staffing Arrangements, Center for Urban Economic Development, Univ. of Chicago, 14, 17-24 (2003.

85 Id.

${ }^{86} \mathrm{Id}$. at 22.

87 To date, OSHA has not yet provided "clear, centralized guidance [...] on the legal responsibilities of temporary staffing agencies or their clients to properly ensure the safety of the day laborers they employ." U.S. GAO, Worker Protection.

${ }^{88}$ Leonard T. Jernigan, Jr. Top Ten Fraud Cases 2010: The Jernigan Law Firm. Found at: www.jernlaw.com/pdf/top_fraud_2010.pdf. (national list of leading fraud cases compiled by North Carolina workers' compensation law firm)

89 The Community Economic Development Center in New Bedford reports that this problem was repeatedly identified when helping immigrant temp workers fill out their tax forms and explaining to these workers that they now have to pay taxes that they did not understand they would owe because of temp employer tax fraud. Interview with Corrin Williams. March, 2011. On file with authors.

90 Michael P. McKinney, "Rhode Island businessman sentenced for fraud, tax evasion," The Providence Journal, Oct. 8, 2010.

91 Mass. Gen. Laws ch. 140, §§ 46A - 46R.

92 Luo, et. al. "The Expanding Role of Temporary Help Services."

93 Commonwealth of Massachusetts, Report of the Commission to Investigate Employment Offices (Boston, 1911), 14.

94 Grace Abbott, Report of the Commission on Immigration on the Problem of Immigration in Massachusetts (Boston, 1914), 40.

95 Id.

96 U.S. Commission on Industrial Relations Vol. 1 Industrial Relations. "Final Report and Testimony." Submitted to Congress by the Commission on Industrial Relations Created by the Act of August 23, 1912 (1916).

97 Mass. Gen. Laws ch. 140, § 46I.

98820 Ill. Comp. Stat. 175/1. et. seq. 
${ }^{99}$ See Warehouse Workers for Justice. 2010. Bad Jobs in Gods Movement: Warehouse Work in Will County, IL. Found at: www.warehouseworkers.org.

100 Interview with Attorney Chris Williams, March 11, 2011. On file with authors; see also Kari Lydersen. "Wal-Mart Warehouse Workers File Class Action Wage Theft Lawsuit," In These Times, Feb. 28, 2011; "A Thriving Industry Built on Low-Compensated Temp Workers," New York Times, August 26, 2010; Warehouse Workers for Justice Blog, Found at: www.warehouseworkers.org.

101 Chris Williams Interview. On file with authors.

102 See e.g. Arrez v. Kelly Services, Inc., 522 F.Supp.2d 997 (N.D.Ill.,2007).

103 Chris Williams Interview.

104 "Illinois Law Aims to Protect Temporary Laborers," EHS Today, June 9, 2005. Found at: http://ehstoday.com/news/ehs_imp_37631/. 